Dressing; Johnson \& Johnson) was used to cover the insertion site in both study groups. Primary study outcomes evaluated were catheter-tip colonization, CR BSI, and BSI without an identified source.

Seven hundred five neonates were enrolled in the trial; 335 were randomized to receive the chlorhexidine dressing and 370 to skin disinfection with PI (controls). Neonates randomized to the antimicrobial dressing group were less likely to have colonized CVC tips than control neonates (15.0\% vs $24.0 \%$; relative risk [RR], $0.6 ; 95 \%$ confidence interval $\left[\mathrm{CI}_{95}\right.$, $0.5-0.9)$. Rates of CR BSI (3.8\% vs 3.2\%; RR, $1.2 ; \mathrm{CI}_{95}, 0.5-2.7$ ) and BSI without a source (15.2\% vs $14.3 \%$; RR, $1.1 ; \mathrm{CI}_{95}, 0.8-$ 1.5) did not differ between the two groups. Localized contact dermatitis from the antimicrobial dressing, requiring crossover into the PI treatment group, occurred in 15 (15.3\%) of 98 exposed neonates weighing $\leqslant 1,000 \mathrm{~g}$. No neonates in the PI group developed contact dermatitis.

The authors concluded that the novel chlorhexidineimpregnated dressing, replaced weekly, was as effective as cutaneous disinfection with $10 \%$ PI and redressing the site every 3 to 7 days for preventing CR BSI and BSI without a source in critically ill neonates requiring prolonged central venous access. The risk of local contact dermatitis under the chlorhexidine dressing limits its use in low-birthweight infants who require prolonged central access during the first 2 weeks of life.

FROM: Garland JS, Alex CP, Mueller CD, Otten D, Shivpuri C, Harris MC, et al. A randomized trial comparing povidone-iodine to a chlorhexidine gluconate-impregnated dressing for prevention of central venous catheter infections in neonates. Pediatrics 2001;107:1431-1436.

\section{Virucidal Activity of Ortho-Phthalaldehyde Solution Against Duck Hepatitis B Virus}

At the recent APIC 2001 meetings in Seattle, Roberts and Chan-Myers reported on studies where orthophthalaldehyde, a new high-level disinfectant alternative to glutaraldehyde, was tested for efficacy against duck hepatitis $B$ virus. Duck hepatitis B virus is accepted by the EPA as the surrogate test virus for human hepatitis B virus. Dilute $(0.3 \%)$ ortho-phthalaldehyde solutions were used in inactivation studies against duck hepatitis $B$ virus contained in whole duck serum. The virus was dried onto the bottom of petri dishes, and a quantity of dilute ortho-phthalaldehyde solution was added. After an exposure of 5 minutes at $20^{\circ} \mathrm{C}$, the virus was recovered and titrated on monolayers of duck hepatocytes.

After incubation there was no viable duck hepatitis B virus detected. In conclusion, the findings of this study demonstrate that ortho-phthalaldehyde solutions are efficacious against duck hepatitis $B$ virus at a 5-minute exposure at $20^{\circ} \mathrm{C}$.
FROM: Roberts C, Chan-Myers HB. Virucidal activity of ortho-phthalaldehyde solution against duck hepatitis B virus. Presented at the 28th APIC Annual Educational Conference and International Meeting; June 10-14, 2001; Seattle, WA.

\section{Hepatitis B and C Viruses: Where Are Germicides Relevant?}

Sattar and colleagues from the Centre for Research on Environmental Microbiology, Faculty of Medicine, University of Ottawa, and the Division of Bloodborne Pathogens, Health Canada, Ottawa, have published an upto-date primer on hepatitis B virus (HBV) and hepatitis C virus (HCV). Both viruses are the most prevalent bloodborne pathogens. Infections caused by these organisms can become chronic and may lead to liver cirrhosis and carcinoma. Limited chemotherapy is now available, but only $\mathrm{HBV}$ can be prevented through vaccination. Both viruses are enveloped and relatively sensitive to many physical and chemical agents; their ability to survive in the environment may not be as high as often believed. As a result, their spread occurs mainly through direct parenteral or percutaneous exposure to tainted body fluids and tissues. Careful screening of, and avoiding contact with, such materials remain the most effective means of protection. Nevertheless, the indirect spread of these viruses, although much less common, can occur when objects that are freshly contaminated with tainted blood enter the body or contact damaged skin.

Germicidal chemicals are important in the prevention of HBV and HCV spread through shared injection devices, sharps used in personal services (such as tattooing and body piercing), heat-sensitive medical or dental devices (such as flexible endoscopes), and in the cleanup of blood spills. Microbicides in vaginal gels also may interrupt their transmission. General-purpose environmental disinfection is unlikely to play a significant role in the prevention of the transmission of these viruses. Testing of low-level disinfectants and label claims for such products against HBV and $\mathrm{HCV}$ should be discouraged. Both viruses remain difficult to work with in the laboratory, but closely related animal viruses (such as the duck HBV) and the bovine viral diarrhea virus show considerable promise as surrogates for $\mathrm{HBV}$ and HCV, respectively. Although progress in the culturing of $\mathrm{HBV}$ and $\mathrm{HCV}$ is still underway, critical issues on virus survival and inactivation should be addressed with the use of these surrogates.

FROM: Sattar SA, Tetro J, Springthorpe VS, Giulivi A. Preventing the spread of hepatitis $B$ and $C$ viruses: Where are germicides relevant? Am J Infect Control 2001;29:187-197. 